\title{
THE EFFECT OF CONTINUOUS INTRAVENOUS ADMINISTRATION OF HISTAMINE ON BASAL METABOLISM IN HUMAN BEINGS
}

\author{
By GUSTAVUS A. PETERS, ${ }^{1}$ BAYARD T. HORTON, AND \\ WALTER M. BOOTHBY \\ (From the Mayo Foundation, Division of Medicine, Mayo Clinic, and the \\ Mayo Aero Medical Unit, Rochester, Minnesota)
}

(Received for publication November 6, 1944)

\section{INTRODUCTION}

In 1922, it was reported that histamine, repeatedly injected subcutaneously into rats for several days, produced little or no effect on metabolism (1). Tests were not made immediately after the subcutaneous injection, the earliest being $11 / 2$ hours after the injection of $20 \mathrm{mgm}$. Only in large doses was there a slight change in metabolism. On the basis of experiments, it was concluded that histamine does not belong to that group of substances which plays a major rôle in metabolic processes.

In 1928 , it was found that a 1 per cent solution of histamine injected subcutaneously in human subjects obtained an 8 to 15 per cent increase in basal oxygen consumption (2).

In 1928, two investigators (3), working with dogs, noted a marked elevation in basal metabolism after subcutaneous injection of 15 to $30 \mathrm{mgm}$. of histamine.

Also, in 1929, it was found that after subcutaneous injection of 0.4 to $0.7 \mathrm{mgm}$. of histamine phosphate into a trained person, a small elevation of metabolism was observed, on an average of 7 per cent (4).

In 1934, two workers (5) gave $1 \mathrm{mgm}$. of histamine subcutaneously to each of 17 human subjects. Eleven showed a considerable decrease in basal metabolic rate, while 6 were within limits of error. They explained their work on the basis of stimulation of the parasympathetic nervous system and paralysis of the sympathetic system. It should be noted that the metabolic measurements were made some time after the injection.

In 1932, the effect of histamine administered intravenously on the basal metabolism of human

\footnotetext{
1 Since this paper was written Dr. Peters has entered the armed forces and is now First Lieutenant, Medical Corps, Army of the United States.
}

subjects was reported (6). An elevation in basal metabolism was obtained as high as 50 per cent in some cases. Considerable variation was shown in degree of elevation of metabolism with similar rates of injection. As far as we know, these investigators were the first to determine the effect of histamine on basal metabolism using the drug intravenously.

During clinical investigations at the Mayo Clinic, the occasion arose to investigate the effect on metabolism of histamine administered intravenously. The results of our studies are consistent with the observations of the latter group of workers (6).

\section{PROCEDURE}

Two sets of experiments were performed. In both sets, the basal metabolic rate was determined before the administration of histamine but in Group I the metabolic rate was not determined again until after the completion of the injection; while in Group II, the metabolic rate was determined during the injection.

Group I. Twenty-three subjects were studied by the Tissot method. Thirteen were men and ranged in age from 22 to 60 years, the average age being 50 years. Ten were women and ranged in age from 26 to 64 years, with an average age of 44 years. Such diagnoses as internal squint, allergic arthritis, headache, angioneurotic edema, postural vertigo, arteriovenous fistula, tinnitus, Parkinson's disease, Ménière's disease, chronic nervous exhaustion, torticollis, chronic infectious arthritis, multiple sclerosis and cyclic edema had been made. The metabolic rate was determined before and after the intravenous administration of histamine. All subjects studied had been without food for 15 or more hours. Of the 23 subjects, 16 showed an increase in metabolic rate of from +1 per cent to +25 per cent, 5 showed a decrease of from -1 per cent to -6 per cent and 2 did not show any change. It appeared likely that a considerable amount of the effect of histamine was being missed by waiting until the completion of the injection. Therefore, a second group of subjects was studied by a different procedure.

Group II. Eleven subjects were studied by means of a modified Benedict-Roth apparatus. Five of these were women and 6 were men. The former ranged in age from 
18 to 34 years, with an average of 27 years, and the latter ranged in age from 31 to 59 years, with an average of 38 years. The metabolic rate of these subjects was determined before, in the course of, and after the intravenous injection of, histamine. They had such diagnoses as Ménière's disease, headache, chronic nervous exhaustion, purpura or urticaria, or were normal subjects. The procedure for this group was to allow the fasting subject to rest quietly in bed for 20 to 30 minutes. Then the basal rate was determined. The oxygen mask was then removed, and the subject was allowed to rest for $10 \mathrm{~min}$ utes. Then, after a subcutaneous injection of 1 per cent solution of procaine hydrochloride over an antecubital vein, an intravenous injection of physiologic saline solution at rates varying from 60 to 240 drops per minute was begun, and the metabolic rate was determined again. After this, a $1: 250,000$ solution of histamine diphosphate was substituted for the saline solution, and rates of injection, usually 4 varying from 0.0066 to $0.0528 \mathrm{mgm}$. of histamine base per minute, were used. During and after each increment in rate of injection, a determination of oxygen consumption was made. A rest period of $10 \mathrm{~min}$ utes with the mask off was allowed between changes of injection rate and before a final basal metabolic rate was determined at the conclusion of the experiment.

As a comparative study, a 1:1,000,000 dilution of epinephrine and physiologic saline solution alone were injected intravenously in a similar fashion as the histamine solution, and the effect on the metabolic rate was observed.

Five subjects were studied under absolutely controlled environmental conditions. The subjects were in a temperature of $78^{\circ} \mathrm{F}$. and a relative humidity of 40 per cent. The oxygen content of the blood from the antecubital vein was determined before and during the height of the administration of histamine.

\section{RESULTS}

The results of this study are summarized in Tables I to IV. In Table I, it is easily observed that increasing amounts of histamine administered intravenously produced a corresponding rise in consumption of oxygen and in the ventilation rate. Additional control observations with saline solution were made on the 11 subjects of Group II, showing that no increase in metabolic rate took place with saline solution, though consistent increase was produced by histamine given during subsequent periods to the same subjects (Table I). Also histamine produced a rise in cardiac rate and a lowering of the blood pressure. The effect on the metabolic rate, however, was soon dissipated after discontinuance of administration of the drug. It is interesting to note that with each doubling of the dose of histamine, the metabolic rate increased approximately twice its former value. At 30 drops per minute, the basal metabolic rate was 4 per cent, at 60 drops it was 14 per cent, at 120 drops it was 29 per cent, and at 240 drops it was 58 per cent.

Table II shows the results obtained with a $1: 1,000,000$ solution of epinephrine. This solu-

TABLE I

Effect of histamine on basal metabolism (mean results in eleven cases)

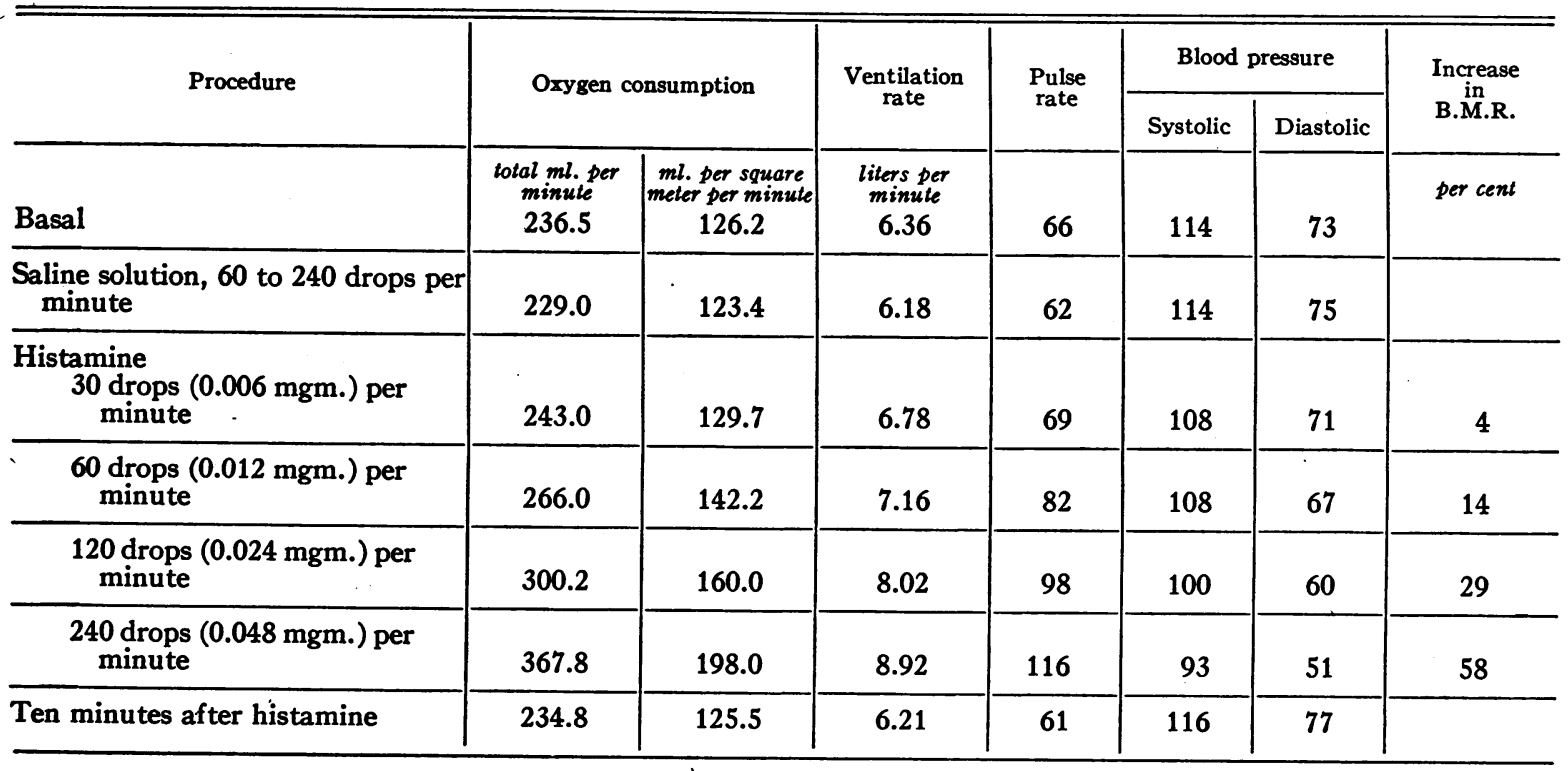


TABLE II

Effect of epinephrine $(1: 1,000,000)$ on basal metabolism (1 case)

\begin{tabular}{|c|c|c|c|c|c|c|c|}
\hline \multirow{3}{*}{ Procedure } & \multirow{2}{*}{\multicolumn{2}{|c|}{ Oxygen consumption }} & \multirow{3}{*}{$\begin{array}{c}\begin{array}{c}\text { Ventilation } \\
\text { rate }\end{array} \\
\begin{array}{c}\text { liters per } \\
\text { minule } \\
5.11\end{array}\end{array}$} & \multirow{3}{*}{$\begin{array}{c}\begin{array}{c}\text { Pulse } \\
\text { rate }\end{array} \\
56\end{array}$} & \multicolumn{2}{|c|}{ Blood pressure } & \multirow{3}{*}{$\begin{array}{c}\begin{array}{c}\text { Increase } \\
\text { in } \\
\text { B.M.R. }\end{array} \\
\text { per cent }\end{array}$} \\
\hline & & & & & \multirow{2}{*}{$\begin{array}{c}\text { Systolic } \\
104\end{array}$} & \multirow{2}{*}{$\begin{array}{c}\text { Diastolic } \\
72\end{array}$} & \\
\hline & $\begin{array}{l}\text { total ml. per } \\
\text { minute } \\
204.4\end{array}$ & $\begin{array}{c}\text { ml. per square } \\
\text { meter per minute } \\
112\end{array}$ & & & & & \\
\hline Saline solution, 240 drops per minute & 193.6 & 106 & 4.93 & 56 & 106 & 74 & \\
\hline $\begin{array}{l}\text { Epinephrine } \\
30 \text { drops per minute }\end{array}$ & 200.8 & 110 & 5.20 & 66 & 103 & 68 & $\mathbf{0}$ \\
\hline 60 drops per minute & 208.0 & 114 & 5.92 & 68 & 116 & 76 & 4 \\
\hline 120 drops per minute & 222.3 & 121 & 7.00 & 74 & 118 & 74 & 12 \\
\hline 240 drops per minute & 222.3 & 121 & 8.07 & 84 & 156 & 94 & 12 \\
\hline Ten minutes after epinephrine & 211.6 & 116 & 5.92 & 64 & 116 & 78 & \\
\hline
\end{tabular}

TABLE III

Effect of physiologic saline solution on basal metabolism (1 case)

\begin{tabular}{|c|c|c|c|c|c|c|}
\hline \multirow{2}{*}{ Procedure } & \multirow{2}{*}{\multicolumn{2}{|c|}{ Oxygen consumption }} & \multirow{2}{*}{$\begin{array}{l}\text { Ventilation } \\
\text { rate }\end{array}$} & \multirow{2}{*}{$\begin{array}{l}\text { Pulse } \\
\text { rate }\end{array}$} & \multicolumn{2}{|c|}{ Blood pressure } \\
\hline & & & & & Systolic & Diastolic \\
\hline Basal & $\begin{array}{c}\text { total ml. per } \\
\text { minute } \\
201.3\end{array}$ & $\begin{array}{c}\text { ml. per square } \\
\text { meter per minute } \\
110.0\end{array}$ & $\begin{array}{c}\text { liters per } \\
\text { minute } \\
5.04\end{array}$ & 50 & 106 & 72 \\
\hline $\begin{array}{l}\text { Saline solution } \\
7 \text { drops per minute }\end{array}$ & 204.9 & 112.0 & 5.13 & 52 & 104 & 74 \\
\hline 30 drops per minute & 169.6 & 92.7 & 4.95 & 50 & 114 & 74 \\
\hline 60 drops per minute & 190.3 & 104.0 & 5.30 & 50 & 114 & 74 \\
\hline 120 drops per minute & 183.0 & 100.0 & 5.30 & 50 & 110 & 78 \\
\hline 240 drops per minute & 183.0 & 100.0 & 5.48 & 48 & 112 & 78 \\
\hline Ten minutes after saline solution & 208.6 & 114.0 & 3.80 & 48 & 112 & 80 \\
\hline
\end{tabular}

TABLE IV

Increase in oxygen content of venous blood during histamine administration*

\begin{tabular}{|c|c|c|c|c|c|c|c|}
\hline \multirow{2}{*}{ Case } & \multirow{2}{*}{ Histamine } & \multicolumn{2}{|c|}{ Before histamine } & \multicolumn{2}{|c|}{ After histamine } & \multirow{2}{*}{ Capacity } & \multirow{2}{*}{$\begin{array}{l}\text { Increase } \\
\text { in } \\
\text { saturation }\end{array}$} \\
\hline & & $\begin{array}{l}\text { Oxygen } \\
\text { content }\end{array}$ & Saturation & $\begin{array}{l}\text { Oxygen } \\
\text { content }\end{array}$ & Saturation & & \\
\hline 1 & $\begin{array}{c}\text { drops per minutet } \\
120\end{array}$ & $\begin{array}{c}\text { volumes per cent } \\
11.4\end{array}$ & $\begin{array}{c}\text { per cent } \\
57\end{array}$ & $\begin{array}{c}\text { volumes per cent } \\
16.7\end{array}$ & $\begin{array}{c}\text { per cent } \\
84\end{array}$ & $\begin{array}{c}\text { volumes per cent } \\
20.0\end{array}$ & $\begin{array}{c}\text { per cent } \\
27\end{array}$ \\
\hline 2 & 160 & 11.5 & 60 & 18.2 & 94.3 & 19.3 & 34 \\
\hline 3 & 120 & 14.1 & 69 & 16.0 & 79 & 20.3 & 10 \\
\hline 4 & 20 to 30 & 13.1 & 62 & 16.9 & 74 & 22.8 & 12 \\
\hline 5 & 20 to 30 & 13.1 & 66 & 18.0 . & 88 & 20.4 & 22 \\
\hline rage & & & & & & & 21 \\
\hline
\end{tabular}

* The subjects were in a basal state, that is without food, and in an environmental temperature of $78^{\circ} \mathrm{F}$. and 40 per cent humidity. 
tion produced only a slight rise in oxygen consumption or an elevation of the basal metabolic rate of 12 per cent. The ventilation rate, cardiac rate, and blood pressure, however, were considerably elevated. The effect of the epinephrine seemed to be more prolonged than that of the histamine after the intravenous injection was discontinued.

Table III shows the effect of physiologic saline solution given in the same way as the solutions of histamine and of epinephrine. The saline solution did not produce any increase of oxygen consumption.

As shown in Table IV, there was an average increase in oxygen saturation of the blood from the antecubital veins of 21 per cent. The percentage of increase ranged from 10 to 34 . The blood in each case was withdrawn under oil without the use of a tourniquet, and the determinations of oxygen were made by the Van Slyke gasometric method. Each subject had been lying in a horizontal position, at rest, for at least 40 minutes,

\section{ACCUMULATIVE EFFECT OF HISTAMINE ON OXYGEN CONSUMPTION}

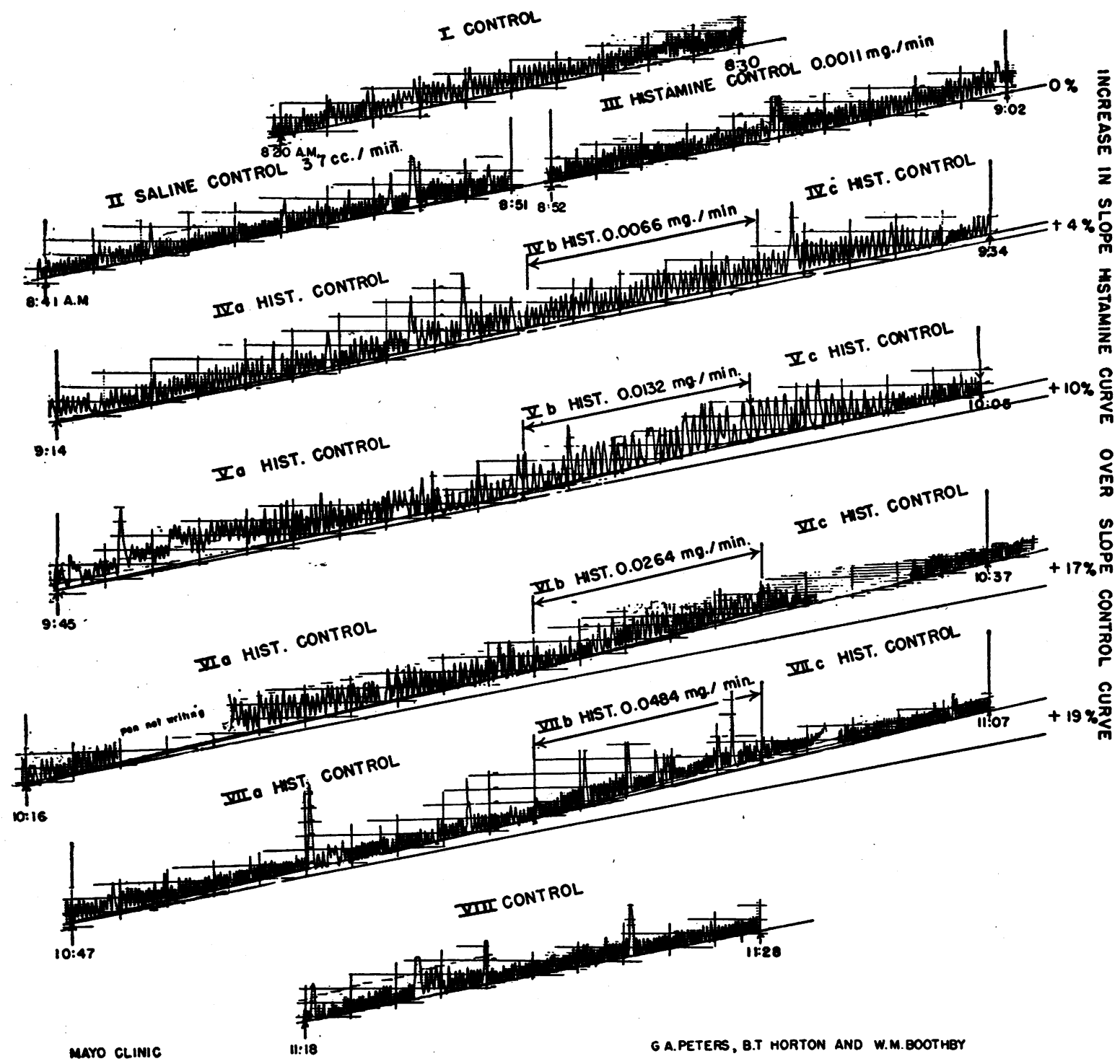

Fig. 1. Metabolic Kymographic Record of 1 of the Subjects, Showing the Effect of Histamine on Metabolism 
before the specimens of blood were withdrawn. The gross appearance of the blood in the veins was observed to be redder and more arterial at the height of the injection of histamine than before injection.

Figure 1 reproduces an actual record of a normal subject, aged 26 years, taken from the Benedict-Roth machine. The kymographic tracing shows the increase in the metabolic rate of from 0 per cent to +19 per cent. It illustrates well the effect on the respiratory rate and how quickly the effect of histamine on oxygen consumption is produced and lost. One subject, a man, aged 59 years, showed a rise in metabolic rate of from -14 per cent to +96 per cent. These 2 subjects represent the extremes in low and high response to histamine respectively. The other subjects were intermediate in their response to histamine. With the same rates of injection, considerable variation of the degree of elevated metabolism was shown by the subjects.

\section{COMMENT}

The basal metabolic rate is a measure of the oxygen consumption for each square meter of body surface; it has been shown to be a measure of heat production. Any substance which brings about an increase of peripheral circulation might cause a greater loss of heat from the body and thus elevate the metabolic rate.

In man, histamine dilates the arterioles and capillaries, and it also causes an increase in capillary permeability. In general, it acts as a secretagogue, particularly to the gastric mucosa. Both actions, no doubt, require the expenditure of energy and may play a part in the increased oxygen consumption. The peripheral vasodilatation resulting from the intravenous administration of histamine is not uniform throughout the human body. Because of the vasomotor gradient, as it exists in man, vasodilatation occurs promptly in the face and neck in most subjects. When the histamine is administered at increased rates, a gradually increasing vasodilatation spreads over the thorax, abdomen, and upper extremities, and it may even extend to the lower extremities. This vasodilatation is inclined to be splotchy in its distribution, especially over the thorax, abdomen, and upper extremities. This is more marked in blonds and redheads than in brunets.
We realize that kymographic records obtained with the closed circuit metabolism apparatus (Benedict-Roth) are subject to errors, and it is possible to explain the apparent increase in oxygen consumption on the basis of alterations in the tidal air. For example, as the functional residual air is gradually expelled during increased respiration, the graph would naturally indicate an increase in oxygen consumption, whereas no actual increase had taken place. To rule out such errors, the same subject, in several instances, was studied for 3 or more hours on 3 to 4 successive days, and no alterations in tidal air could be demonstrated as a possible explanation for increased oxygen consumption. Furthermore, such an explanation could not account for the increased oxygen consumption, as measured by the Tissot method.

\section{CONCLUSIONS}

Histamine has been shown to increase oxygen consumption during intravenous injection, and the increase as measured is roughly proportional to the rate at which histamine is given in one series. This effect ceases soon after administration is stopped, thus differing from the effect of such "calorigenic" substances as thyroxine. Further study is needed to determine the reason for this increased oxygen consumption.

\section{BIBLIOGRAPHY}

1. Abelin, J., Beiträge zur Kenntnis der physiologischen Wirkung der proteinogenen Amine. Biochem. Ztschr., 1922, 129, 1.

2. Grab, W., Untersuchung über den respiratorischen Stoffwechsel des Menschen bei Muskelarbeit unter Wirkung von Histamin. Ztschr. f. d. ges. exper. Med., 1928, 63, 360.

3. Knipping, H. W., and Steiger, J., Uber die Wirkung einiger Amine. Ztschr. f. d. ges. exper. Med., 1929, 64, 594.

4. von Euler, U., and Liljestrand, G., Die Wirkung von Adrenalin, Sympathol, Tyramin, Ephetonin und Histamin auf Gaswechsel und Kreislauf beim Menschen. Skandinav. Arch. f. Physiol., 1929, 55, 1.

5. Dzsinich, A., and Pély, M., Änderung des Grundumsatzes im Histaminshock. Klin. Wchnschr., 1934, 13, 699.

6. Weiss, S., Robb, G. P., and Ellis, L. B., The systemic effects of histamine in man; with special reference to the responses of the cardiovascular system. Arch. Int. Med., 1932, 49, 360. 